\title{
FAKTOR YANG MEMENGARUHI NILAI PERUSAHAAN MANUFAKTUR YANG TERDAFTAR DI BEI
}

\author{
Lukman Surjadi
}

Program Studi Akuntansi Universitas Tarumanagara

Email: Lukman_surjadi@yahoo.com

\begin{abstract}
ABSTRAK
Tujuan dilakukannya penelitian ini yaitu untuk menganalisa pengaruh dari Leverage, Profitability, dan kebijakan dividen terhadap nilai perusahaan secara signifikan atau tidak. Populasi yang digunakan pada penelitian ini adalah perusahaan manufaktur yang terdaftar di Bursa Efek Indonesia pada periode 2015-2017. Teknik yang digunakan dalam pengumpulan sampel yakni purposive sampling, dengan sampel sebanyak 34 perusahaan dan 102 data perusahaan. Hasil penelitian yang diperoleh yaitu Leverage dan kebijakan deviden memiliki pengaruh positif terhadap nilai perusahaan, Profitability memiliki pengaruh negatif terhadap nilai perusahaan.
\end{abstract}

Kata kunci: Leverage, Profitability, Kebijakan Dividen, dan Nilai Perusahaan.

\section{ABSTRACT}

The purpose of this research is to analyze the effect of board of Leverage, Profitability, and dividend policy on firm value significant or not. Population used in this research are manufacturing company listed in Indonesian Stock Exchange on period 2015-2017. The technique used in collecting samples that is purposive sampling, with a sample of 34 companies and 102 company data. Result of research obtained are Leverage and dividend policy have positive effect to firm value, Profitability have negative effect to firm value.

Keywords: Leverage, Profitability, Dividend Policy, and Firm Value.

\section{PENDAHULUAN}

\section{Latar Belakang}

Karena globalisasi, maka mendorong terbentuknya persaingan antara perusahaan yang semakin ketat. Oleh karena hal tersebut, perusahaan berlomba-lomba untuk meningkatkan kinerjanya yang bisa kita lihat dari nilai perusahaan itu sendiri. Nilai perusahaan adalah sesuatu yang sangat penting bagi perusahaan, karena tujuan dari perusahaan yang utama adalah untuk meningkatkan dan menaikkan nilai perusahaan itu sendiri (Siti Meilani Wandini Putri, 2014.)

Perusahaan adalah bentuk badan kegiatan usaha yang bertujuan untuk mendapatkan keuntungan yang besar dan maksimal. Perusahaan tentu memiliki suatu tujuan. Tujuan perusahaan ada yang bersifat jangka pendek dan ada pula yang bersifat jangka panjang. Dalam kegiatan perekomian perusahaan memiliki peran yang teramat penting. Dalam perekonomian perusahaan memiliki peran sebegai produsen, distributor, agen pembangunan, dan konsumen. Dan juga memiliki peran untuk penyerapan tenaga kerja atau penciptaan lapangan pekerjaan. Kinerja suatu perusahaan adalah nilai perusahaan. Nilai perusahaan suatu perushaan tentu bisa baik dan juga bisa buruk.

Nilai perusahaan merupakan suatu nilai wajar suatu perusahaan yang dapat menggambarkan pandangan dan presepsi pemilik modal terhadap emiten tersebut. Menurut Husnan (2000 dalam Veronica Hasibuan, Moch Dzulkirom AR, dan N G Wi Endang NP, 2016), nilai perusahaan adalah harga yang bersedia dibayar oleh calon pembeli apabila perusahaan dijual. 
Variabel Leverage merupakan faktor yang dapat mempengaruhi nilai suatu perusahaan. Leverage adalah presentase tersedianya dana yang dimiliki oleh pemegang saham terhadap pemberi pinjaman. Apabila rasionya tinggi, artinya rendah dana yang disediakan oleh pemegang saham. Semakin rendah rasio Leverage, maka akan semakin baik kemampuan sebuah perusahaan untuk membayar hutang jangka panjangnya. Dan apabila semakin tinggi Leverage berarti semakin besar hutang daripada modal perusahaan tersebut. Apabila hutang suatu perusahaan semakin besar, semakin kecil pula jumlah laba yang dapat diterima oleh perusahaan.

Variabel Leverage tentunya dapat mempengaruhi nilai suatu perusahaan. Menurut Kasmir (2008), Leverage adalah sebuah rumus rasio yang dapat digunakan untuk menilai utang sebuah perusahaan dengan ekuitasnya. Karena apabila rasio Leverage semakin tinggi, maka nilai perushaan akan semakin buruk dimata penanam modal. Karena pemegang saham atau calon investor akan melihat bahwa perusahaan tersebut memiliki daya modal yang rendah daripada hutangnya. Sedangkan sebaliknya, apabila Leverage semakin kecil, maka nilai perusahaan akan semakin baik, karena modal yang dimiliki lebih besar daripada hutang perusahaan tersebut.

Variabel Profitability adalah rasio keuangan perusahaan dengan mengukur kekuatan dan potensi suatu perusahaan untuk membuahkan profit pada tingkat pendapatan, aset, dan juga modal saham. Semakin tinggi Profitability, maka nilai perusahaan semakin tinggi dan hal ini akan bagus untuk perusahaan tersebut. Akan tetapi, semakin rendah Profitability, maka akan semakin rendah dan buruk nilai suatu perusahaan. Jadi, apabila Profitability suatu perusahaan tinggi, maka hal itu akan dipandang baik oleh investor dan calon penanam modal perusahaan yang bersangkutan.

Menurut Weston dan Copeland (1999) fungsi Profitabilty adalah untuk mengukur dan menghitung seberapa efektifnya perusahaan itu untuk memanfaatkan sumber dayanya yang ada dan dimiliki, yang dapat disebut sebagai pengembalian dari investasi. Sedangkan hasil dari pengembalian invesstasi tersebut merupakan rasio yang dapat memperlihatkan hasil dari seberapa besar jumlah aktiva yang dipakai dan digunakan oleh perusahaan (Kasmir, 2008).

Selain variabel Leverage dan Profitability, kebijakan deviden juga merupakan hal yang sangat vital untuk meningkatkan atau justru memperburuk nilai perusahaan. Kebijakan deviden adalah suatu hasil keputusan yang diambil oleh sebuah petinggi perusahaan untuk membagikan hasil labanya kepada para pemegang saham perusahaan itu sendiri. Tentunya ada beberapa penanam modal yang sangat berharap dari deviden perusahaan yang mereka investasikan. Tidak semua orang hanya berharap pada harga nilai sahamnya saja, tetapi juga dari deviden yang bisa perusahaan bagikan kepada mereka. Semakin besar deviden yang dibagikan, maka akan semakin besar juga minat investor untuk terus bahkan menambahkan lagi modalnya dalam perusahaan tersebut.

Hasil keputusan untuk membagikan deviden terhadap para penanam modal dalam perusahaan akan mempegaruhi harga dari saham perusahaan tersebut dan tentunya nilai perusahaan itu akan meningkat dengan sendirinya (Al-Malkawi, 2007; Rahmawati \& Akram, 2007).

Berdasarkan latar belakang yang sudah penulis jabarkan diatas, maka penulis sanagt tertarik untuk melakukan sebuah penelitian yang lebih dalam lagi. Oleh karena itu maka penulis akan menganalisis beberapa faktor-faktor yang mempengaruhi nilai perusahaan yang terdaftar di BEI selama tahun 2015-2017 yaitu Leverage, Profitability, dan kebijakan deviden. 


\section{Teori keagenan}

Teori keagenan (Agency theory) adalah basis atau dasar teori yang mendasari praktik bisnis dari suatu perusahaan yang dipakai selama ini. Teori ini berasal dari sinergi dari teori keputusan teori ekonomi, sosiologi dan teori organisasi. Teori ini memiliki prinsip utama menyatakan adanya hubungan kerja antara pihak pemberi wewenang (principal) dengan pihak penerima wewenang (agency) yang adalah manajer dalam bentuk suatu kontrak kerja sama. Godfrey (2010:362) menyatakan bahwa: hubungan agensi dikatakan telah terjadi ketika suatu kontrak antara seseorang atau lebih seorang principal dan orang lainnya, seorang agen, untuk memberikan jasa demi kepentingan pemberi wewenang (principal) termasuk melibatkan pemberian delegasi kekuasaan pengambilan keputusan kepada penerima wewenang (agency). Baik principal maupun agency diasumsikan untuk termotivasi hanya oleh kepentingan diri sendiri yaitu, untuk memaksimalkan kegunaan subjek mereka dan juga untuk menyadari kepentingan bersama mereka. Ada dua alasan yang dapat mengarah kepada terjadinya divergensi atau perbedaan antara kepentingan diri sendiri dengan perilaku koperatif: Yang pertama adalah adanya masalah informasi yang timbul ketika agen memakai informasi khusus yang tidak dapat diverifikasi oleh principal untuk mengimplementasikan dengan baik suatu aturan yang berbeda dari keinginan principal. Hal ini membuat principal tidak dapat menentukan apakah pihak agency telah membuat keputusan yang tepat atau tidak. Sedangkan yang kedua adalah masalah moral yang bisa timbul ketika muncul masalah motivasional atau konflik sebagai akibat perbedaan kesepakatan dengan kontrak yang sudah dijanjikan sejak awal.

Eisenhardt dalam Siagian (2011:11) menyatakan bahwa teori agensi memakai tiga asumsi sifat dasar manusia yaitu:

1 Manusia umumnya selalu mementingkan kepentingan diri sendiri (self interest).

2 Manusia memiliki daya pikir terbatas mengenagi persepsi masa mendatang (bounded rationality).

3 Manusia selalu menghindari resiko (risk averse).

Konsep Agency Theory menurut Anthony dan Govindarajan dalam Siagian (2011:10) adalah suatu hubungan atau kontak antara principal dan agent. Principal sebagai pihak yang mempekerjakan agent untuk melakukan tugas untuk kepentingan principal, termasuk dalam pendelegasian otorisasi pengambilan keputusan dari principal kepada agent. Pada perusahaan yang modalnya terdiri dari saham, peran principal dipegang oleh pemegang saham dan CEO (chief executive officer) sebagai agent mereka. Para pemegang saham mempekerjakan CEO untuk bertindak sesuai dengan kepentingan para pemegang saham. Berdasarkan uraian-uraian yang telah dijelaskan, maka dapat ditarik kesimpulan bahwa agency theory timbul disebabkan karena adanya hubungan kontrak antara satu pihak dengan pihak yang lain yang memiliki hubungan untuk melakukan suatu tindakan atas nama pemberi tanggung jawab (principal).

\section{Teori Sinyal}

Teori Sinyal (Signalling Theory) berpendapat bahwa perusahaan harus menjalankan tugasnya yaitu memberikan sinyal kepada para penanam modal dan para investor. Sinyal bisa berupa informasi dan pemberitahuan mengenai hal-hal apa saja yang dilakukan oleh pihak manajemen di dalam suatu perusahaan. Kegunaan dalam teori ini adalah untuk mengurangi asimetri atas informasi antara pihak yang berada dalam perusahaan atau pihak internal terhadap pihak luar perusahaan atau pihak eksternal.

Menurut Rio Milanda (2012), teori sinyal menggambarkan peran dan keharusan perusahaan memberikan sinyal dalam laporan keuangan. Jadi kesimpulan dan penjelasan dari apa yang sudah diuraikan adalah bahwa teori sinyal dapat dan digunakan untuk memberi gambar dan 
informasi yang sangat penting dan vital dari pihak internal perusahaan terhadap pihak eksternal perusahaan khusunya para investor dan pemegang saham. Tentunya teori ini dapat berpengaruh terhdap kebijakan deviden suatu perusahaan, oleh karena asimetri informasi dan perusahaan harus memberikan kualitas informasi yang dapat lebih baik lagi ke depannya karena para investor dan pemegang saham dapat mengambil suatu keputusan dan pertimbangan yang sangat matang untuk mengambil tindakan dan menanamkan modalnya di dalam perusahaan tersebut.

\section{Leverage}

Variabel Leverage adalah rasio yang menunjukkan apakah modal yang dimiliki oleh perusahaan tersebut dapat menutupi dan melunasi utang-utangnya kepada eksternal. Jadi apabila rasio Leverage semakin kecil maka akan semakin baik untuk perusahaan. Menurut Leli Amnah Rakhimsyah dan Barbara Gunawan (2011) Leverage yang nilainya tinggi akan menjelaskan bahwa hutang perusahaan tersebut besar, akan tetapi hutang dapat digunakan untuk menjadi suatu modal untuk memutar dan menjalankan kegiatan perusahaan untuk memperoleh laba yang maksimal yang nantinya tentu akan menambah dan menaikkan nilai sebuah perusahaan tersebut dimata publik. Kemudian menurut Eugene F. Bringham dan Joel F. Houston (2011:7) bahwa semua perusahaan memiliki dan mempunyai struktur atas modal yang optimal, yang dinyatakan sebagai perpaduan antara kewajiban, preferen, dan ekuitas akan menyebabkan harga jual saham perusahaan itu menjadi optimal. Dimana struktur modal itu dapat dihitung dan diukur menggunakan Leverage.

\section{Profitability}

Menurut Riyadi (2006), Profitability merupakan sebuah rasio untuk mengukur profitabilitas yang memperlihatkan adanya perbandingan diantara laba perusahaan dengan total asset dari perusahaan tersebut. Kasmir (2008) menuturkan, hasil dari pengembalian suatu investasi adalah rasio yang menunjukkan return atas jumlah asset atau harta yang dipergunakan oleh perusahaan. Menurut Mardiyanto (2009), Profitability merupakan rasio untuk mengukur dan menilai sebuah kemampuan entitas dalam menghasilkan laba yang didapat dari aktivitas investasi yang ada. Menurut Lestari dan Sugiharto (2007) Profitability baik apabila diatas 2\%. Semakin besar Profitability, maka semakin baik karena berarti semakin efisien pula penggunaan aktiva atau harta perusahaan dan hal ini menunjukkan dengan jumlah harta yang sama bisa menghasilkan keuntungan yang lebih besar.

\section{Kebijakan Deviden}

Menurut Dwi Cahyaningdyah dan Yustieana Dian Ressany (2012), kebijakan dividen adalah suatu bentuk keputusan keuangan, pertimbangan tentang apakah dengan membayar dividen akan meningkatkan kemakmuran dari para pemegang saham. Penentu dari kebijakan dividen antara lain adalah profitabilitas perusahaan, proporsi kepemilikan saham, umur perusahaan, dan ukuran perusahaan. Penentuan keputusan tentang kebijakan dividen akan mempengaruhi nilai saham dan nilai perusahaan. Tujuan perusahaan dari pembagian deviden adalah guna memaksimalkan kesejahteraan pemilik perusahaan tersebut, di samping menjalankan keuangan yang cukup untuk perusahaan itu. Apabila penghasilan perusahaan naik, tidak menjamin manajemen perusahaan akan meningkatkan deviden. Tetapi jika manajemen perusahaan yakin akan terjadi peningkatan pendapatan perusahaan, maka nilai dividen dapat ditingkatkan. Jadi dapat ditarik kesimpulan bahwa setiap perusahaan memiliki 2 opsi untuk kebijakan deviden, yaitu membagikan deviden tersebut kepada para pemegang saham perusahaan atau menahan deviden untuk diinvestasikan kembali untuk perusahaan. 


\section{Nilai Perusahaan}

Pengertian nilai perusahaan menurut Azhari (2018) adalah nilai yang digambarkan melalui tingkat kemampuan perusahaan dalam mensejahterahkan para pemiliknya yang diukur menggunakan PBV yaitu nilai pasar per lembar saham kemudian dibagi dengan nilai buku per lembar saham. Nilai perusahaan adalah keadaan yang telah dicapai perusahaan dari awal didirikan sampai saat ini. Nilai perusahaan yang tinggi tentu adalah hal yang sangat diinginkan oleh pemiliknya. Karna tingginya nilai perusahaan berarti kesejahtraan pemilik perushaan juga baik. Nilai perusahaan mempengaruhi minat para calon pembeli yang ada di pasar modal, apabila nilai perusahaan tinggi, maka jumlahnya pembeli juga akan semakin tinggi karna ingin melakukan investasi di perusahaan tersebut. Jadi dapat disimpulkan bahwa nilai perusahaan adalah nilai kepercayan investor terhadap perusahaan melalui kemampuan perusahaan dalam memenuhi keinginan pemilik saham dan tergambarkan oleh harga saham di pasar modal.

Kerangka pemikiran dalam penelitian ini seperti digambarkan dibawah ini:

Variabel Independen

Variabel Dependen

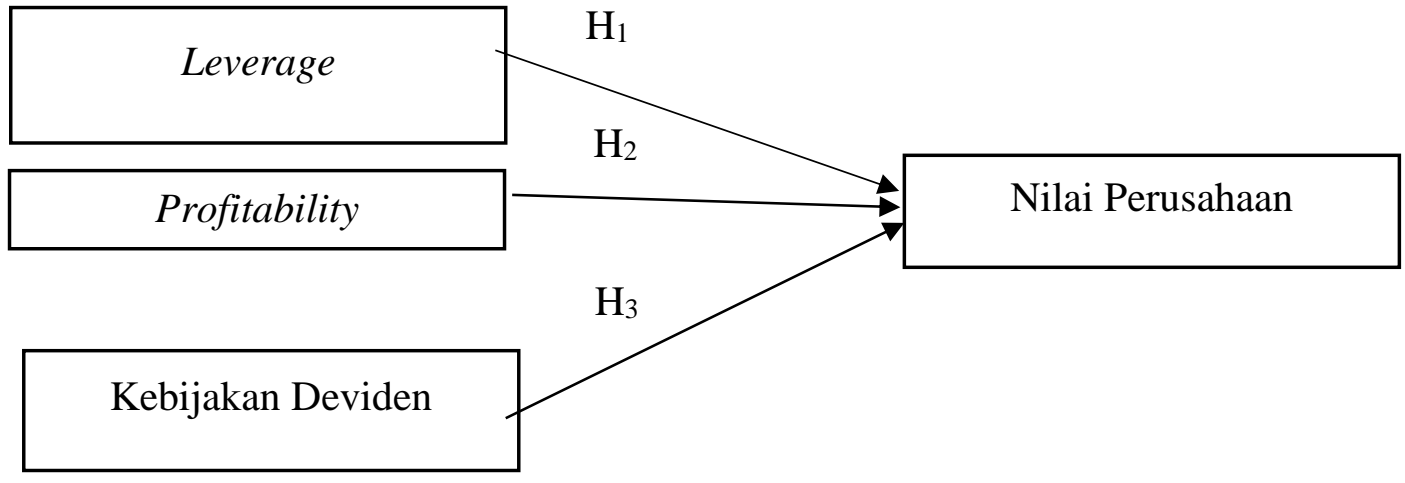

Hipotesis dari model yang dibangun di atas adalah sebagai berikut:

H1: Terdapat pengaruh positif dan signifikan Leverage terhadap nilai perusahaan.

H2: Terdapat pengaruh negatif dan signifikan Profitability terhadap nilai perusahaan.

H3: Terdapat pengaruh positif dan signifikan kebijakan deviden terhadap nilai perusahaan.

\section{METODE PENELITIAN}

Desain penelitian yang digunakan bersifat deskriptif yang berguna untuk mendapat informasi mengenai pengaruh Profitability, Leverage, dan Kebijakan Dividen terhadap Nilai Perusahaan. Metode yang digunakna dalam penelitian ini adalah metode kuantitatif yang datanya berada di Bursa Efek. Variabel yang akan digunakan dalam penelitian ini ada 3 variabel independen dan 1 variabel dependen. 3 variabel independen yang digunakan yaitu Leverage, Profitability, dan Kebijakan Dividen. Variabel dependen yang akan digunakan dalam penelitian ini adalah Nilai Perusahaan.

Populasi yang akan digunakan dalam penelitian ini adalah perusahaan-perusahaan yang terdaftar dalam Bursa Efek Indonesia (BEI) dalam periode 2015-2017. Dari populasi tersebut, sampel yang akan diambil adalah perusahaan secara keseluruhan yang ada dalam Bursa Efek Indonesia tersebut. Metode pengambilan sampel yang akan digunakan dalam pengambilan sampel tersebut adalah Purposive Sampling. Purposive Sampling merupakan cara memilih sampel yang memilih sampel tertentu dengan menggunakan kriteria tertentu dalam menentukan sampel. Kriteria tertentu yang akan digunakan dalam melakukan pemilihan sampel tersebut adalah: perusahaan manufaktur yang terdaftar didalam Bursa Efek Indonesia pada periode 2015-2017, perusahaan manufaktur yang sudah menerbitkan laporan keuangannya secara lengkap dalam periode 2015- 
2017, perusahaan manufaktur yang menghasilkan laba selama periode 2015-2017, perusahaan manufaktur yang menerbitkan laporan keuangan dengan mata uang rupiah selama periode 20152017, dan perusahaan manufaktur yang melakukan pembagian dividen selama tahun 2015-2017.

\begin{tabular}{cccc}
\hline No. & Variabel & Ukuran & Skala \\
\hline 1. & Leverage & Leverage $=\frac{\text { Total Debt }}{\text { Total Equity }}$ & Rasio \\
\hline 2. & Profitability & Profitability $=\frac{\text { Net Income }}{\text { Total Asset }}$ & Rasio \\
\hline 3. & $\begin{array}{c}\text { Dividend Payout } \\
\text { Ratio }\end{array}$ & $\begin{array}{l}\text { Dividend Payout Ratio } \\
\text { Dividend per Share }\end{array}$ & Rasio \\
& $=\frac{\text { Earning per Share }}{\text { Firm Value }}$ & PBV $\quad$ Harga Pasar Saham & Rasio \\
\hline 4. & Filai buku per Lembar Saham & \\
\hline
\end{tabular}

Dalam penelitian ini pertama-tama dilakukan analisis regresi data panel dengan menentukan teknik analisis data panel yaitu Common Effect Model (CEM), Fixed Effect Model (FEM), Random Effect Model (REM). Untuk menentukan teknik analisis data panel yang sesuai dan terbaik untuk digunakan dalam penelitian ini, maka dilakukan Uji Chow dan Uji Lagrange Multiplier. Selanjutnya melakukan MoLeverageate Regression Analysis (MRA) untuk mengetahui apakah variabel moLeverageating akan memperkuat atau memperlemah hubungan antara variabel independen dan variabel dependen.

Hipotesis pada penelitian ini diuji menggunakan uji t ( $t$-test), uji $\mathrm{F}$ (ANOVA), dan uji koefisien determinasi $\left(\mathrm{R}^{2}\right)$. Kemudian, metode yang digunakan adalah metode analisis regresi berganda untuk menguji pengaruh Leverage, Profitability dan kebijakan devien terhadap nilai perusahaan. Persamaan model regresi untuk penelitian ini adalah sebagai berikut:

\section{PBV $=\alpha+\beta_{1}$ LEVERAGE - $\beta_{2}$ PROFITABILITY $+\beta_{3}$ DIVIDEND PAYOUT RATIO $+\varepsilon$}

Keterangan:

\begin{tabular}{|c|c|}
\hline$Y$ & $=$ Nilai Perusahaan \\
\hline & $=$ Konstanta \\
\hline$\beta_{1} \beta_{2} \beta_{3} \beta_{4}$ & $=$ Koefisien regresi \\
\hline$X_{1}$ & $=$ Leverage \\
\hline$X$ & $=$ Profitability \\
\hline$X_{3}$ & $\begin{array}{l}=\text { Kebijakan Devider } \\
=\text { Error }\end{array}$ \\
\hline
\end{tabular}

\section{HASIL DAN PEMBAHASAN}

\section{Hasil Uji Statistik}

Uji Chow atau likelihood adalah tahap pengujian pertama yang dilakukan untuk memilih model estimasi data panel yang terbaik diantara Common Effect Model, Random Effect Model, dan Fixed Effect Model. Hasil dari uji Chow dalam penelitian ini mendapatkan hasil nilai probabilitas pada cross section $F$ sebesar 0.0000. Nilai ini lebih kecil dibandingkan dengan tingkat 
signifikansi sebesar 0.05 yang berarti $\mathrm{H} 0$ ditolak, maka model estimasi yang terpilihi dari hasil uji chow atau likelihood adalah random effect model. Pada penelitian ini maka random effect akan digunakan untuk membentuk persamaan model regresi yang berfungsi untuk menganalisis regresi ganda, uji F atau uji ANOVA, uji T, uji koefisien determinasi (adjusted $R$-square) serta untuk pengujian hipotesis.

Tabel 1. Hasil Analisis Regresi Berganda

Dependent Variable: NILAI_PERUSAHAAN_Y

Method: Panel EGLS (Cross-section random effects)

Date: 11/14/19 Time: 23:00

Sample: 20152017

Periods included: 3

Cross-sections included: 35

Total panel (balanced) observations: 105

Swamy and Arora estimator of component variances

\begin{tabular}{|c|c|c|c|c|}
\hline Variable & Coefficient & Std. Error & t-Statistic & Prob. \\
\hline C & 3.203891 & 3.202751 & 1.000356 & 0.3195 \\
\hline LEVERAGE_X1 & 5.099371 & 2.323496 & 2.194698 & 0.0305 \\
\hline PROFITABILITY_X2 & -0.057958 & 0.196166 & -0.295453 & 0.7683 \\
\hline \multirow[t]{3}{*}{$\mathrm{DP}_{-} \mathrm{X} 3$} & 0.229069 & 1.171354 & 0.195559 & 0.8453 \\
\hline & \multirow{2}{*}{\multicolumn{2}{|c|}{ Effects Specification }} & & \\
\hline & & & S.D. & Rho \\
\hline \multirow{3}{*}{$\begin{array}{l}\text { Cross-section random } \\
\text { Idiosyncratic random }\end{array}$} & & & 14.65484 & 0.8951 \\
\hline & & & 5.017385 & 0.1049 \\
\hline & \multicolumn{3}{|c|}{ Weighted Statistics } & \\
\hline R-squared & 0.047288 & \multirow{5}{*}{\multicolumn{2}{|c|}{$\begin{array}{l}\text { Mean dependent var } \\
\text { S.D. dependent var } \\
\text { Sum squared resid } \\
\text { Durbin-Watson stat }\end{array}$}} & 1.393108 \\
\hline Adjusted R-squared & 0.018989 & & & 5.013768 \\
\hline S.E. of regression & 4.965936 & & & 2490.712 \\
\hline F-statistic & 1.671037 & & & 2.313389 \\
\hline Prob(F-statistic) & 0.000000 & & & \\
\hline \multicolumn{5}{|c|}{ Unweighted Statistics } \\
\hline R-squared & 0.060782 & \multicolumn{2}{|c|}{ Mean dependent var } & 7.184095 \\
\hline Sum squared resid & 23018.37 & \multicolumn{2}{|c|}{ Durbin-Watson stat } & 0.250321 \\
\hline
\end{tabular}

Setelah dilakukan analisis regresi berganda, model persamaan regresi berganda yang didapatkan adalah:

$Y=3.203891+5.099371 \mathrm{X}_{1}-0.057958 \mathrm{X}_{2}+0.229069 \mathrm{X}_{3}+\varepsilon$

Dari persamaan regresi diatas, dapat diartikan bahwa nilai apabila nilai Leverage, Profitability, dan Dividend Payout Ratio adalah sama dengan 0 maka nilai PBV adalah sebesar 3.203891 satuan. Jika nilai Leverage naik satu satuan dan variabel Profitability dan Dividend Payout Ratio adalah konstan maka nilai PBV akan naik sebesar 5.099371 satuan. Jika nilai Profitability naik satu satuan, dan variabel Leverage dan Dividend Payout Ratio adalah konstan maka nilai PBV akan turun sebesar 0.057958 satuan. Jika nilai Dividend Payout Ratio naik sebesar satu satuan dan variabel Leverage dan Profitability adalah konstan, maka PBV akan naik sebesar 0.229069 satuan. 
Uji $\mathrm{F}$ atau biasa juga disebut dengan uji ANOVA dilaksanakan untuk menguji apakah variabelvariabel independen dapat mempengaruhi variabel dependen secara simultan atau bersama-sama. Berdasarkan hasil pengujian uji $\mathrm{F}$ diketahui bahwa nilai dari Prob (F-Statistic) yaitu nilai signifikansi untuk uji F sebesar $0.000000(0.00000<0.05)$ hal ini berarti adalah nilai uji signifikansi $\mathrm{F}$ lebih rendah dibandingkan dengan 0.05 sehingga dapat ditarik kesimpulan bahwa variabel independen yaitu variabel Leverage, Profitability, dan Dividend Payout Ratio (kebijakan deviden) dapat mempengaruhi variabel dependen yaitu PBV (nilai perusahaan) secara bersama-sama (simultan). Berdasarkan hasil dari uji F ini maka dapat ditarik kesimpulan bahwa model regresi dalam penelitian ini layak untuk digunakan.

Uji t dilakukan untuk melihat pengaruh dari masing-masing variabel independen secara individu atau parsial terhadap variabel dependen. Apabila tingkat signifikansi $(\alpha)$ kurang dari 0,05 artinya variabel independen mempunyai pengaruh signifikan terhadap variabel dependen. Selanjutnya, tentukan arah variabel independen terhadap variabel dependen, jika nilai koefisien variabel independen menunjukkan nilai positif, maka variabel independen berpengaruh positif terhadap variabel dependen dan sebaliknya. Hasil uji t nilai koefisien untuk variabel Leverage menunjukkan arah positif. Lalu, nilai probabilitas variabel Leverage sebesar 0.0305 dimana nilai probabilitas lebih kecil daripada tingkat signifikansi sebesar 0.05 (0.0305 < 0.05). Secara statistik, Leverage berpengaruh positif signifikan terhadap nilai perusahaan. Nilai koefisien untuk variabel Profitability menunjukan arah negatif. Nilai probabilitas variabel Profitability sebesar 0.057958 dimana nilai probabilitas lebih besar daripada tingkat signifikansi sebesar 0.05 $(0.057958>0.05)$. Secara statistik, Profitability berpengaruh negatif, tidak signifikan terhadap nilai perusahaan. Nilai koefisien untuk variabel kebijakan deviden menunjukan arah positif. Nilai probabilitas variabel kebijakan deviden sebesar 0.229069 dimana nilai probabilitas lebih besar daripada tingkat signifikansi sebesar 0.05 (0.229069 > 0.05). Secara statistik, kebijakan deviden berpengaruh positif, tidak signifikan terhadap nilai perusahaan.

Uji koefisien determinasi atau $\mathrm{R}^{2}$ dilakukan untuk mengukur seberapa jauh kemampuan variabel independen yaitu Leverage, Profitability, dan kebijakan deviden dalam menerangkan varian variabel dependen yaitu nilai perusahaan. Adjusted $R$ Square digunakan untuk menentukan nilai koefisien determinasi. Besarnya nilai koefisien determinasi adalah diantara nol (0) dan satu (1), yaitu $0<\mathrm{R}^{2}<1$. Jika nilai koefisien determinasi semakin mendekati 1 maka semakin tinggi kemampuan variabel-variabel independen Leverage, Profitability, dan kebijakan deviden. Berdasarkan hasil dari uji adjusted $R^{2}$ didapatkan hasil sebesar 0.018989 yang berarti bahwa $1,8989 \%$ variabel nilai perusahaan (PBV) dapat dijelaskan oleh variabel independen Leverage, Profitability, dan kebijakan deviden. Sisanya sebesar 0.981011 atau 98,1011\% dapat dijelaskan dengan variabel-variabel lainnya selain dari variabel dalam penelitian ini. Berdasarkan hasil uji koefisien determinasi, nilai dari adjusted $R$-squared dalam penelitian ini mendekati angka 0 maka dapat disimpulkan nilai koefisien determinasi pada penelitian ini kecil sehingga dapat ditarik kesimpulan bahwa kemampuan variabel independen seperti Leverage, Profitability, dan kebijakan deviden untuk dapat menjelaskan nilai perusahaan (PBV) sebagai variabel dependen sangat terbatas.

\section{Diskusi}

Dalam penelitian ini dapat diambil kesimpulan bahwa hipotesis pertama, Leverage berpengaruh positif dan signifikan terhadap nilai perusahaan. Dalam penelitian ini, hipotesis tersebut diterima karena hipotesis tersebut signifikan. Hipotesis kedua, Profitability berpengaruh negatif dan signifikan terhadap nilai perusahaan, dalam penelitian ini, hipotesis tersebut ditolak karena hipotesis tersebut tidak signifikan. Hiotesis ketiga, kebijakan dividen berpengaruh tidak 
signifikan terhadap nilai perusahaan, hipotesis tersebut ditolak karena hasil dari penelitian ini menunjukkan bahwa hipotesis tersebut tidak signifikan. Berikut penjelasan mengenai ketiga hipotesis diatas: Hasil pengujian parsial (uji t) menunjukkan bahwa tingkat signifikansi Leverage terhadap nilai perusahaan adalah sebesar 0.0305 , yang berarti nilai tersebut lebih kecil dari 0.05 . Hasil tersebut menunjukkan bahwa variabel Leverage sebagai variabel independen memiliki pengaruh yang signifikan terhadap variabel nilai perusahaan sebagai variabel dependen. Nilai ini sesuai dengan Ha1 yang digunakan dalam penelitian ini karena Leverage berpengaruh secara signifikan terhadap nilai perusahaan pada perusahaan manufaktur yang terdaftar dalam Bursa Efek Indonesia (BEI) pada periode 2015-2017. Hasil uji parsial (uji t) dalam penelitian ini menunjukkan bahwa tingkat signifikansi dari pengaruh Profitability terhadap nilai perusahaan adalah sebesar 0.057958 yang berarti nilai tersebut lebih besar dari 0.05. Hasil tersebut menunjukkan bahwa Profitability sebagai variabel independen berpengaruh signifikan terhadap nilai perusahaan sebagai variabel dependen. Nilai ini tidak sesuai dengan Ha2 yang digunakan dalam penelitian ini yaitu pada perusahaan manufaktur yang terdaftar dalam Bursa Efek Indonesia (BEI) pada periode 2015-2017. Hasil uji parsial (uji t) pada penelitian ini mengenai pengaruh kebijakan dividen sebagai variabel independen terhadap nilai perusahaan sebagai variabel dependen menunjukkan tingkat signifikansi sebesar 0.229069 , hasil ini lebih besar dari 0.05. Berdasarkan hasil tersebut, dapat disimpulkan bahwa variabel kebijakan dividen memiliki pengaruh tidak signifikan terhadap variabel nilai perusahaan. Hasil ini tidak sesuai dengan Ha3 yang digunakan dalam penelitian ini karena hasil dari penelitian ini kebijakan dividen tidak signifikan terhadap nilai perusahaan pada perusahaan manufaktur yang terdaftar pada periode 2015-2017.

\section{KESIMPULAN DAN SARAN}

Berdasarkan analisis data dan pembahasan hasil penelitian dapat disimpulkan bahwa variable Leverage berpengaruh positif dan signifikan terhadap nilai perusahaan pada perusahaan Manufaktur yang terdaftar di BEI pada periode 2015-2017. Leverage berpengaruh positif yang artinya semakin tinggi rasio Leverage yang dimiliki perusahaan akan meningkatkan nilai perusahaan, sebaliknya apabila rasio Leverage yang dimiliki perusahaan rendah maka akan menurunkan nilai perusahaan dimata pasar dan investor. Leverage signifikan terhadap nilai perusahaan yang menunjukan bahwa perubahan yang terjadi pada Leverage akan meningkatkan nilai atau menurunkan nilai perusahaan. Profitability berpengaruh negatif dan tidak signifikan terhadap nilai perusahaan pada perusahaan manufaktur yang terdaftar di BEI pada periode 20152017. Pengaruh Profitability nagatif terhadap nilai perusahaan yang artinya semakin tinggi rasio Profitability yang ada di dalam perusahaan akan menurunkan pula nilai perusahaan di mata para investor. Profitability tidak signifikan terhadap nilai perusahaan yang menunjukan bahwa perubahan yang terjadi pada Profitability tidak akan meningkatkan nilai atau menurunkan nilai perusahaan. Kebijakan dividen berpengaruh positif dan tidak signifikan terhadap nilai perusahaan manufaktur yang terdaftar di BEI pada periode 2015-2017.

Keterbatasan dalam penelitian ini adalah hanya ada tiga faktor yang mempengaruhi nilai perusahaan dalam penelitian ini, yaitu Leverage, Profitability dan kebijakan dividen sedangkan masih banyak faktor lain yang dapat mempengaruhi nilai perusahaan, sampel penelitian yang digunakan hanya pada perusahaan manufaktur yang terdapat di Bursa Efek Indonesia pada periode 2015-2017, sampel yang digunakan hanya 34 perusahaan karena adanya kriteria yang ada dan hal ini masih sangat sedikit, dan Periode dalam penelitian ini hanya tiga tahun yaitu selama tahun 2015-2017. 
Dengan adanya keterbatasan dalam penelitian ini, maka peneliti memberikan saran untuk penelitian selanjutnya yaitu saran akademis dari penelitian ini adalah : penelitian ini dapat dijadikan sebagai refrensi bacaan untuk membuat penelitian yang akan datang, memberikan pengetahuan mengenai nilai perusahaan bagi pihak yang membaca penelitian ini, penelitian selanjutnya menggunakan periode yang lebih dari 3 tahun agar hasil penelitian lebih bervariatif, sektor penelitian selanjutnya ditambahkan lagi agar dapat mencerminkan kejadian secara keseluruhan, dan peneliti selanjutnya dapat menambahkan variabel independen sehingga penelitian selanjutnya lebih bervariatif.

\section{REFERENSI}

Ajija, Shochrul Rohmatul, dkk. 2011. Cara Cerdas Menguasai Eviews. Jakarta: Salemba Empat. Al-Malkawi, H.N. 2007. Determinants of Corporate Dividend Policy in Jordan: An Application of the Tobit Model. Journal of Economic and Administrative Sciences. Vol. 23, Issue 2, pp:44-70.

Azhari (2018). Pengaruh Kebijakan Dividen, Kebijakan Hutang Dan Profitabilitas Terhadap Nilai Perusahaan Manufaktur Sektor Pertambangan Yang Terdaftar Di Bursa Efek Indonesia Periode 2009-2014. JOM FISIP, 5(1), 1-18.

Bringham, Eugene F. dan Joel F. Houston. 2011. Dasar-dasar Manajemen Keuangan. Edisi 11. Penerjemah Ali Akbar Yulianto. Salemba Empat, Jakarta.

Cahyaningdyah Dwi dan Ressany Yustieana Dian (2012). Pengaruh Kebijakan Manajemen Keuangan Terhadap Nilai Perusahaan. JDM. 3(1), 20-28.

Godfrey, Jayne M. et al. (2010). Accounting Theory. 7th edition. New York: John Wiley \& Sons, Inc.

Julianti Dewi. (2015). Pengaruh Rasio Hutang (LEVERAGE) dan Profitabilitas (PROFITABILITY) Terhadap Nilai Perusahaan (PBV) Studi Pada Perusahaan Manufaktur Sub Sektor Otomotif Dan Komponen Yang Terdaftar Di Bursa Efek Indonesia Periode 2012-2014. Universitas Komputer Indonesia.

Kasmir. (2008). Analisis Laporan Keuangan. Jakarta: PT. Raja Grafindo Persada

Lestari, M.I. \& Sugiharto, T. (2007). Kinerja bank devisa dan bank non devisa dan faktor-faktor yang mempengaruhinya. Proceeding PESAT (Psikologi, Ekonomi, Sastra, Arsitek \& Sipil), 2. Fakultas Ekonomi, Universitas Gunadarma.

Leli Amnah Rakhimsyah dan Barbara Gunawan. 2011. Pengaruh Keputusan Investasi, Keputusan Pendanaan, Kebijakan Dividen dan Tingkat Suku Bunga Terhadap Nilai Perusahaan. Jural Investasi. Vol. 7, No. 1, Hlm. 31-45.

Mardiyanto, H. (2009). Intisari Manajemen Keuangan. Jakarta: Grasindo.

Milanda Rio (2012). Pengaruh Kebijakan Manajemen Keuangan Terhadap Nilai Perusahaan (Studi Empiris Perusahaan Manufaktur Yang Listing Di Bei Tahun 2009 - 2011). 1-12.

Onasis Kristie dan Robin (2016). Pengaruh Tata Kelola Perusahaan Terhadap Nilai Perusahaan Pada Perusahaan Sektor Keuangan Yang Terdaftar di BEI. Vol. 20, No. 1, Hlm. 1-22.

Ramdhani Rani (2013). Pengaruh Return On Assets Dan Debt To Equity Ratio Terhadap Harga Pasar Saham Pada Institusi Finansial Di Bursa Efek Indonesia. Journal The Winners. Vol. 14, No. 1, Hlm. 29-41.

Ranupandojo dan Husnan. 2000. "Organisasi dan Motivasi: Pasar Peningkatan Produktivitas”, Bumi Angkasa, Jakarta.

Riyadi, S. (2006). Banking Assets and Liability Management. Edisi 3. Jakarta: Lembaga Penerbit Fakultas Ekonomi Universitas Indonesia

Sondang P. Siagian. (2011). Manajemen Sumber Daya Manusia, Jakarta: PT. Bumi Aksara. 
Siti Meilani Wandini Putri. 2014. Pengaruh Dividend Payout Ratio (DPR), Debt Equity Ratio (LEVERAGE), Return On Asset (PROFITABILITY), dan Size Perusahaan Terhadap Nilai Perusahaan. E-Journal Fakultas Ekonomi Universitas Maritim Raja Ali Haji

Sugiyono (2012). Metode Penelitian Kuantitatif Kualitatif dan R\&D. Bandung: Alfabeta.

Veronica Hasibuan, Moch Dzulkirom AR, N G Wi Endang NP. 2016. Pengaruh Leverage Dan Profitabilitas Terhadap Nilai Perusahaan. (Studi Pada Perusahaan Property Dan Real Estate Yang Terdaftar Di Bursa Efek Indonesia Periode Tahun 2012-2015). Malang

Weston, J. Fred; Thomas E.Copeland, 1999, Manajemen Keuangan, Edisi Kesembilan, Jilid 2, Jakarta: Binarupa Askara

Weygandt, Donald (2011). Financial Accounting IFRS Edition. United States of America: John Wiley \& Sons Inc. 